ISBN 978-93-84468-94-1

International Conference on Education, Business and Management (ICEBM-2017)

Bali (Indonesia) Jan. 8-9, 2017

\title{
Factors Affecting Marathon Athletes' Behavior on Purchasing Supplementary Health Foods
}

\author{
Sutham Phongsamran, Suthamas Onkon \\ Postgaduat School of Business administration Kasembundit University, Bangkok \\ planning@kbu.ac.th
}

\begin{abstract}
The purpose of this study is to determine factors affecting Marathon athlete's behavior and marketing mix on purchasing supplementary health foods. The samples were 300 marathon athletes who used to compete in marathon racing by using a check list and rating scale questionnaire as a tool. Statistical application used for data analysis was percentage, mean, standard deviation, Chi Square, and regression analysis. Findings from the study indicated that most of respondents were males, age 30-39 years old, married status, government employees, and average monthly income 20,000-30,000 baht. Marathon athletes' behavior on purchasing supplementary health foods revealed that most of respondents spent 500-1,000 baht per month each time when they purchased powder supplementary health foods and self-made decision. The average picture of the opinion of factors that affecting Marathon athlete's behavior and marketing mix on purchasing supplementary health foods were in high level which emphasized on products, distribution channel, prices, and marketing promotion, respectively.

Products aspect revealed that the factors of marketing mix, such as products were correlated to marathon athlete's behavior on purchasing supplementary health foods. When considered in each aspect found that sizes of supplementary health foods are suitable to carry along. Prices aspect revealed that the factors marketing mix, such as prices were correlated to marathon athlete's behavior on purchasing supplementary health foods. When considered in each aspect found that the prices are negotiable and appropriate to quality.

Distribution channel aspect revealed that the factors marketing mix, such as distribution channel were correlated to marathon athlete's behavior on purchasing supplementary health foods. When considered in each aspect found that the retail stores are nationwide.Marketing promotion aspect revealed that the factors marketing mix, such as marketing promotion were correlated to marathon athlete's behavior on purchasing supplementary health foods. When considered in each aspect found that the sales representative are knowledgeable with courtesy. Recommendations from the study were that retailers should stretch priority to group of age between 21-30 years old, new packages design, including marketing promotion, give priority to prices bargaining, wide range of prices that appropriate to products quality, good location with easy access, offer products through e-commerce, available products on the display, and display product samples at the retail stores and online so that consumers are easily to decide.
\end{abstract}

Keyword: Factors Affecting

\section{Introduction}

Nutrition is a key factor in health to strengthen human body in general, athletes stretch to whole protein nutrient from supplementary foods to build muscular strength and their confidence, especially for athletes today. Therefore, health supplementary foods become part of everyday life of athletes and consumer because food nutrient get reduced from food processing system with complex food production 
process. In addition, consumer eating habits are changing and turn into eating too much greasy fast food or oily daily products which give little fibers, the risk of causing malnutrition and certain disease, the National Bureau of statistics, Ministry of information and communication technologies (2550), scientific evidence confirms that consumption of supplements food correctly can strengthen human body and reduce the chance of getting disease, such as cancer, heart disease, and vascular disease but consumption of supplementary health foods in excessive amount could become a punishment correspondingly. Those consumer who needed supplementary health food should get information in details instead of getting information which persuaded by advertising manufacturers, consult with the doctors, especially pregnant lady when taking supplementary health foods. In the field of manufacturing of health supplements, entrepreneur should conduct its business with integrity and honesty to consumer, should not offered food complements that do not have quality standard and pretend to indicate to exceed the reality.

\section{Purpose of the Study}

The primary purpose of this study is to determine factors affecting Marathon athlete's behavior and marketing mix on purchasing supplementary health foods.

\section{Research Methodology}

\subsection{Sample selection}

The samples were 300 marathon athletes who used to compete in marathon racing.

\subsection{Data collection procedure}

The questionnaires were distributed to sample of 300 marathon athletes who used to compete in marathon racing. A total of 300usable questionnaires were returned back to the researcher, yielding a 100 percent response rate and no missing data.

The overall picture of the opinions regarded factors affecting Marathon athlete's behavior and marketing mix on purchasing supplementary health foods were in high level, such as products aspect $(\bar{x}=4.43)$, prices aspect $(\bar{x}=3.54)$, but distribution channel aspect $(\bar{x}=3.37)$, marketing promotion aspect $(\bar{x}=3.13)$ were in medium level of the opinions.

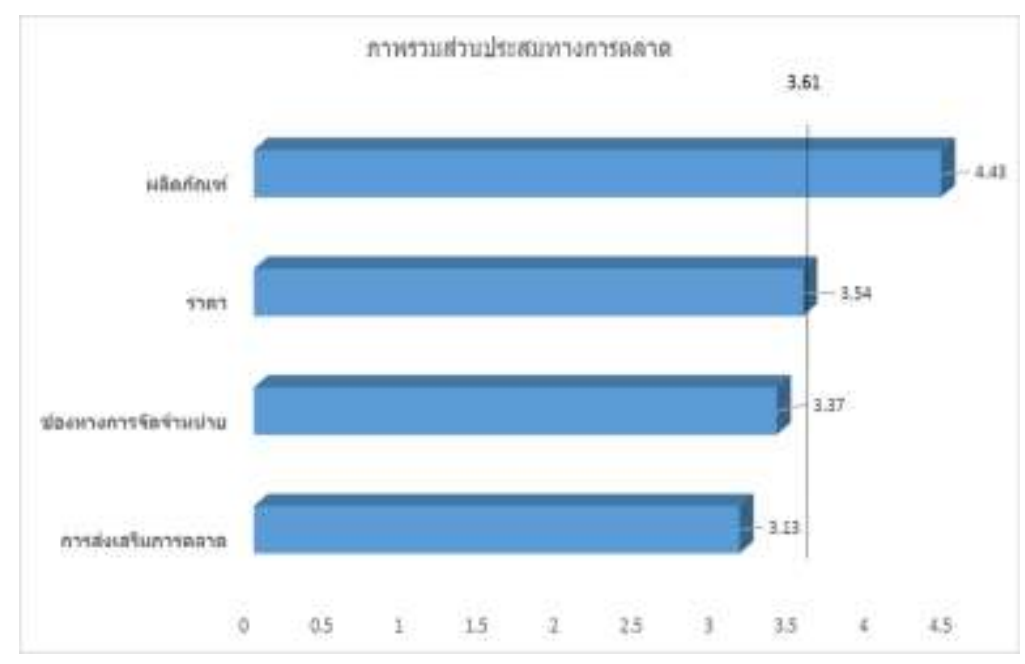

Fig. 1: shows the overall picture of the opinion

The overall average picture of the opinion revealed that marketing mix factors affecting Marathon athlete's behavior on purchasing supplementary health foods were in high level, such as products aspect 
$(\bar{x}=4.43)$, prices aspect $(\bar{x}=3.54)$, but distribution channel aspect $(\bar{x}=3.37)$, and marketing promotion $(\bar{x}=3.13)$ were in medium level.

TABLE I: Factors of marketing mix correlated with marathon athlete's behavior on purchasing supplementary health foods

\begin{tabular}{|c|c|c|c|c|c|c|}
\hline Marketing mix & $\mathrm{B}$ & Std. error & Beta & $\mathrm{t}$ & Sig. & results \\
\hline Constant & 1.772 & .406 & & 4.364 & .000 & \\
\hline \multicolumn{7}{|c|}{ Products aspect } \\
\hline 1. Quality and benefit & -.011 & .010 & .057 & -1.103 & .271 & No relation \\
\hline 2. Packages of products & .247 & .080 & .239 & 3.081 & $.002 * *$ & relationship \\
\hline 3. Tastes of products & .052 & .080 & .053 & .646 & .519 & No relation \\
\hline 4. Quantity of products & .102 & .057 & .126 & 1.810 & .071 & No relation \\
\hline $\begin{array}{l}\text { 5. Information label, such } \\
\text { as exp. Date }\end{array}$ & .070 & .060 & .075 & 1.162 & 246 & No relation \\
\hline 6. FDA approval sticker & 203 & .068 & .190 & 2.970 & $.003 * *$ & relationship \\
\hline 7. New products & .077 & .049 & .100 & 1.583 & .114 & No relation \\
\hline \multicolumn{7}{|c|}{ Prices aspect } \\
\hline $\begin{array}{l}\text { 8. Prices appropriate with } \\
\text { quality }\end{array}$ & .000 & .068 & .000 & -.006 & 995 & No relation \\
\hline $\begin{array}{c}\text { 9. Prices appropriate with } \\
\text { quantity }\end{array}$ & .062 & .074 & .073 & -.845 & .399 & No relation \\
\hline $\begin{array}{c}\text { 10. Prices higher than } \\
\text { other brands }\end{array}$ & 120 & .077 & .143 & 1.568 & .118 & No relation \\
\hline $\begin{array}{l}\text { 11. Prices lower than other } \\
\text { brands }\end{array}$ & -.085 & .068 & .103 & -1.253 & 211 & No relation \\
\hline \multicolumn{7}{|c|}{ Distribution channel } \\
\hline $\begin{array}{l}\text { 12. Offers to all retail } \\
\text { stores }\end{array}$ & -.045 & .055 & .065 & -.817 & .414 & No relation \\
\hline $\begin{array}{l}\text { 13. Offers only to } \\
\text { distributor }\end{array}$ & -.034 & .064 & .0 .46 & -.533 & .594 & No relation \\
\hline $\begin{array}{l}\text { 14. order products to many } \\
\text { channels }\end{array}$ & -.009 & .048 & .014 & -.195 & .846 & No relation \\
\hline \multicolumn{7}{|c|}{ Marketing promotion } \\
\hline $\begin{array}{l}\text { 15. Advertising through } \\
\text { media }\end{array}$ & .053 & -.009 & .084 & .927 & 355 & No relation \\
\hline 16. Sales representative & .042- & .053 & .064 & .619 & .573 & No relation \\
\hline 17. Sales promotion & .102 & .042- & .064 & .619 & .146 & No relation \\
\hline 18. A trade show booths & .102 & .047 & .128 & -1.379 & .169 & No relation \\
\hline 19. Direct sales & .125 & .102 & .172 & 1.799 & $.000 * *$ & relationship \\
\hline
\end{tabular}

*Significant level 0.05

\section{Summary of study results}

The purpose of this study is to determine factors affecting marathon athlete's behavior and marketing mix on purchasing supplementary health foods. The samples were 300 marathon athletes who used to compete in marathon racing by using a check list and rating scale questionnaire as a tool. Statistical application used for data analysis was percentage, mean, standard deviation, Chi Square, and regression analysis. 
The overall picture of marketing mix factors revealed that the average picture of the opinions were in high level, such as products aspect, distribution channel aspect, prices aspect, and marketing promotion aspect.

Products aspect revealed that factors of marketing mix, such as products aspect correlated with marathon athlete's behavior on purchasing supplementary health foods when considered in each aspect found that marketing mix such as supplementary health foods packages are compact and portable.

Prices aspect revealed that factors of marketing mix, such as prices aspect correlated with marathon athlete's behavior on purchasing supplementary health foods when considered in each aspect found that marketing mix such as prices can be negotiated, and appropriate to quality.

Distribution channel aspect revealed that factors of marketing mix, such as distribution channel aspect correlated with marathon athlete's behavior on purchasing supplementary health foods when considered in each aspect found that marketing mix such as offered at retail stores nationwide.

Marketing promotion aspect revealed that factors of marketing mix, such as marketing promotion aspect correlated with marathon athlete's behavior on purchasing supplementary health foods when considered in each aspect found that marketing mix such as knowledgeable sales persons, and service with courtesy.

\section{Recommendations from the study}

Recommendations from the study were that retailers should stretch priority to group of age between 21-30 years old, new packages design, including marketing promotion, give priority to prices bargaining, wide range of prices that appropriate to products quality, good location with easy access, offer products through e-commerce, available products on the display, and display product samples at the retail stores and online so that consumers are easily to decide.

\section{Suggestions for future research}

This study explored the factors that influence the buying behavior of marathon athlete's on supplementary health foods. For future research should study supplementary health foods to different category, such as protein type, mineral waters, etc.

\section{References}

[1] Jintana Gomutpong. (2553). Marketing mix and consumer behavior. Thesis, Sukho Thai Thammatirach publisher.

[2] Jirawan Sawanlarb. (2553). Marketing mix factors affecting consumer behavior on purchasing Supplementary health foods in Soonnuen district, Nakorn Ratchasima province. Thesis, Sukho Thai Thammatirach publisher

[3] Pitchayamas Vanthong. (2555). Guideline on marketing management on supplementary health foods, Independent study, Master of Business Administration, Kasem Bundit University.

[4] Pimmalai Goodman. (2555). Factors affecting consumer behavior on choosing supplementary Health foods, Independent Study, Master of Business Administration, Kasem Bundit University. 